\title{
Creating an Innovative Environment for Industrial Companies Internationalization in Ukraine: Prospects and Risks
}

\author{
Natalia Korzh \\ Department of management and \\ administration \\ Vinnytsia Institute of Trade and \\ Economics of Kyiv National University \\ of Trade and Economics \\ Vinnytsia, Ukraine \\ https://orcid.org/0000-0002-4901-3078
}

\author{
Iryna Semeniuk* \\ Department of management and \\ administration \\ Vinnytsia Institute of Trade and \\ Economics of Kyiv National University \\ of Trade and Economics \\ Vinnytsia, Ukraine \\ https://orcid.org/0000-0002-9211-4907 \\ Vitalii Sharko \\ Department of commodity science, \\ expertise and commercial business \\ Vinnytsia Institute of Trade and \\ Economics of Kyiv National University \\ of Trade and Economics \\ Vinnytsia, Ukraine \\ https://orcid.org/0000-0001-5830-8911
}

\author{
Natalia Makhnachova \\ Department of management and \\ administration \\ Vinnytsia Institute of Trade and \\ Economics of Kyiv National University \\ of Trade and Economics \\ Vinnytsia, Ukraine \\ https://orcid.org/0000-0003-4634-2009
}

\begin{abstract}
A high level of innovation is the main precondition for providing the competitiveness of industrial products in the foreign market. This paper deals with the identification of the prospects and risks of creating an innovative environment to stimulate the internationalization of industrial companies. It was determined that the main elements of such an innovative environment are: the innovation ecosystem, human capital, the level of scientific research and the level of introduction of new technologies. Based on data analysis, the paper investigates the main trends in the development of innovative activity in Ukraine during the last five years. The construction of the trend model showed that the Global Innovation Index score of Ukraine tends to increase by an average of 0.55 points annually. The paper also presents a detailed analysis of prospects and risks of creating and developing an innovative environment for promoting the internationalization of Ukrainian industrial companies. It was found that this process is impossible without solving the problems of financing education and science, stimulating the scientific cooperation of industrial companies with scientific organizations and universities, as well as creating an appropriate innovation ecosystem.
\end{abstract}

Keywords-innovative environment, internationalization, industrial companies, innovation ecosystem, innovative activity

\section{INTRODUCTION}

According to the Export Strategy of Ukraine (20172021), one of the main preconditions for the effective functioning of the national economy, the key to its dynamic development and, accordingly, a strategic objective is the large-scale growth of Ukraine's presence in foreign markets. However, in the context of growing international competition, there is a clear interdependence between the innovative development and the increase in foreign trade activity of the company. At the same time, the emergence of new business models influenced by the digital revolution is another challenge for Ukrainian exporters, which requires the introduction of new approaches to managing human capital, data and processes.

During the last five years, there was a positive rating dynamic of Ukraine as an innovative country. In 2018 Ukraine moved 20 positions up in Global Innovation Index compared to 2014 [1]. However, the commodity structures of exports continue to be dominated by industrial products with low added value, which indicates a low innovation activity of Ukrainian companies.

Many recent studies confirm the role of innovation in the internationalization process of a company [2-7]. The innovative environment creates favorable conditions for the development of foreign economic activity of industrial producers, providing competitive advantages in foreign markets. Integral elements of the innovative environment are the innovation ecosystem, human capital, the level of scientific research and the level of introduction of new technologies. These elements are the subjects of research in this paper.

\section{METHODS}

\section{A. Data analysis}

The data sources of this research are the following:

- official websites - Global Innovation Index, The World Bank, State Statistics Service of Ukraine, SCImago Journal \& Country Rank, European Innovation Scoreboard, Ukrainian Innovation Park UNIT.City, Ministry of Education and Science of Ukraine;

- recent studies of Ukrainian and foreign scientists. 


\section{B. Statistical analysis}

The method of trend model construction was used in this paper. The result allowed predicting the prospects for the development of innovative activity in Ukraine.

The basis of calculations is the indicators of the Global Innovation Index score of Ukraine. The trend model was determined based on the following linear equation:

$$
y=b t+a
$$

where y is the Global Innovation Index score of Ukraine; $\mathrm{b}$ and a are trends;

$t$ is a period of time.

An analytical method for equalization of an index series (Least Square Method) was also applied. So, the following system of equations was defined:

$$
\begin{gathered}
a n+b \sum t=\sum y \\
a \sum t+b \sum t^{2}=\sum y^{*} t
\end{gathered}
$$

The trend model was built in MS Excel.

\section{SWOT analysis.}

It is an effective strategic analysis tool that allows evaluating the strengths and benefits of creating an innovative environment.

In its turn, weaknesses and threats can be perceived as strategic areas that need to be reformed to create a favorable innovative environment to strengthen the internationalization process of Ukrainian industrial enterprises.

\section{RESULTS}

In world practice, an innovation ecosystem is seen as a company's ability to produce high value-added products using the synergy and network effects that can occur between the actors of such a system [8].

A well-developed innovation ecosystem would allow Ukrainian industrial companies to mobilize all the necessary resources required for the production and export of innovative products. Now the legal, economic and organizational frameworks of state regulation and implementation of innovative activities in Ukraine are determined by the Law on Innovation Activities and the Law on Priority Directions of Innovation Activities. Over the past five years, the Innovation Development Council, the National Committee for Industrial Development, and the Export Promotion Office have been established. Also, various industry associations and unions at the state and local levels are actively functioning. But, at the same time in Ukraine, there is no integral and effective innovation ecosystem as an element of the innovative environment for internationalization of industrial companies. A model of such an innovative ecosystem could look like Figure 1.

This model represents a group of subjects (actors) interested in the creation of an innovative product that interacts based on close relationships and participates in the creation of an Innovation Platform. Such subjects are Government, Ukrainian industrial companies, foreign and domestic investors, research organizations and universities, foreign industrial companies, non-governmental organizations, and international organizations.

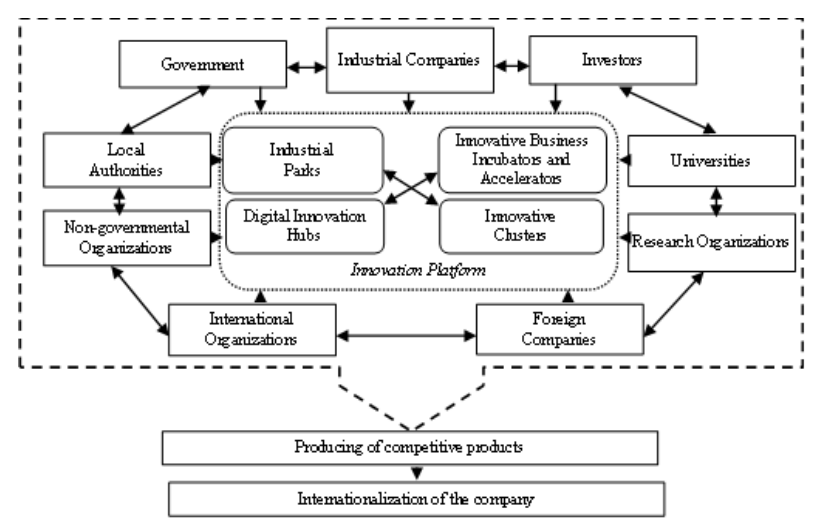

Fig. 1. Model of an innovation ecosystem as an element of the innovative environment for internationalization of industrial companies.

In modern conditions, the main problem is not the number of created innovative products as a result of the interaction of model subjects (actors). The main problem is in evaluating the results of introducing innovations based on utility and efficiency.

Performance indicators of created innovations may be the level of innovation introduction by industrial companies and the share of the number of innovative products in the total volume of export of the industrial company.

As noted previously, for the functioning of the proposed innovation ecosystem, it is necessary to create effective communication channels between subjects (actors). Unfortunately, producers of industrial products do not yet see mutual benefits in partnership with research organizations and universities. Very often, they prefer to import innovative products from developed countries.

Human capital is one of the most important elements of an innovative environment. According to the World Bank, in 2018 Ukraine took the 50th place among 157 countries in the human capital ranking (Human Capital Index) [9]. Taking into account the average Human Capital Index of European countries and countries of Central Asia is about 0.70 , the position of Ukraine with an indicator of 0.65 is relatively good.

Based on official statistics [10], it can be argued that the average population of Ukraine decreased by $1.6 \%$ in 2018 compared with 2014. This, in turn, led to a decrease in the working-age population by $8.9 \%$, as well as a decrease in college graduates by $29.8 \%$ and universities graduates by $11.8 \%$.

During 2014-2018 there was also a reduction in the number of people employed in industry by $17.2 \%$. This is evidence of the lack of qualified personnel to meet the needs of industrial companies. The cuts in state budgetary expenses for education and graduates specialization according to educational sectors will not favor a solution to the problem. For example, in 2018, 27.9\% of colleges graduates received education in the field of health care, $20 \%$ in the field of pedagogy, $17 \%$ in the field of management and administration, $6.9 \%$ in the field of production and technology, and only $4.2 \%$ in the field of engineering.

According to the State Statistics Service of Ukraine, in 2015-2017 the share of labor migrants in the total population 
aged $15-70$ was $4.5 \%$ or 1.3 million people. Most of all, there was an outflow of migrant workers with vocational education (33.9\%). At the same time, only $16.4 \%$ of the total number of labor migrants had full high education. However, it should be noted that almost half of this number $(48.5 \%)$ are shortterm labor migrants.

In this context, under the influence of the digital revolution and the active implementation of the newest technologies by leading international companies, there is an urgent need to increase investment in human capital, both by the State and industrial companies, including the development of the dual form of education, informal education and adult education.

Production and export of innovative industrial products are impossible without providing the appropriate level of scientific research. It can be characterized based on the indicators presented in Figure 2.

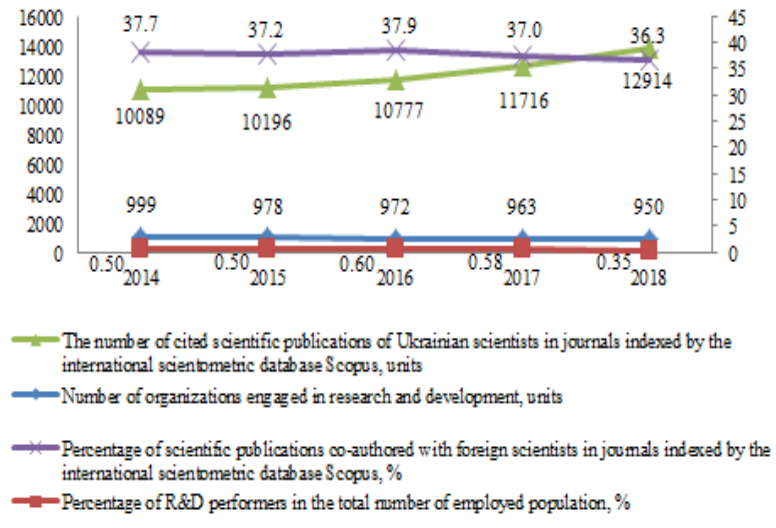

Fig. 2. Main indicators of the results of scientific activities in Ukraine in 2014-2018 [10,11]

According to the Figure 2, the number of organizations engaged in research and development decreased by $4.9 \%$ over five years. The percentage of $R \& D$ performers in the total number of employed population and percentage of scientific publications co-authored with foreign scientists in journals indexed by the international scientometric database Scopus also decreased by $0.15 \%$ and $1.4 \%$, respectively. However, the number of cited scientific publications of Ukrainian scientists in journals indexed by the international scientometric database Scopus increased by $28 \%$.

Another important indicator of the level of scientific research is the Index of Public-private co-publications by million population, which reflects the degree of interaction and cooperation between research organizations and industrial companies. For Ukraine in 2018, this indicator was 4.1, while in 2014 it was only 1.0. But this result is the lowest among European countries. For example, Index of Public-private co-publications by million population in 2018 for Denmark was 315.1, for the Czech Republic - 73.0, for Estonia - 63.8, for Hungary - 59.9, for Poland - 23.1, and Bulgaria - 17.5 [12].

According to the results of studies presented in the report by specialists of the Ukrainian Innovation Park UNIT.City, 124 thousand patents for inventions and utility models were registered in Ukraine during 2007-2017. This is one of the highest rates in the world [13]. At the same time, the largest number of patents for inventions and utility models are owned by foreign companies.

Over the past five years, Ukraine has been actively integrating into the European research space. Now, 189 Ukrainian organizations are participating in 139 projects of the Horizon 2020 Program. As a result, 22.2 million euros were attracted to these projects [14].

In 2018, according to the European Innovation Scoreboard, Ukraine ranked the lowest position ("modest innovator") among the European countries, sharing it with countries such as Romania, Northern Macedonia and Bulgaria [10]. This was the result of the low level of new technologies introduction by industrial companies during the last years (Figure 3).

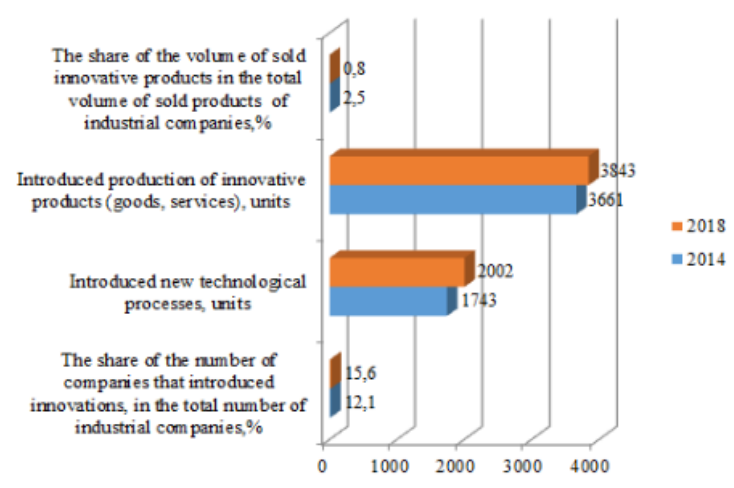

Fig. 3. Results of new technologies introduction by Ukrainian industrial companies in 2014 and 2018 [10]

As shown in Figure 3, in 2018 Ukrainian industrial companies demonstrated better indexes of innovation activity than in 2014. But such results are not sufficient to accelerate the process of internationalization. The main reason is that the share of the volume of sold innovative products in the total volume of sold products of industrial companies has decreased significantly - by more than three times.

The data analysis showed mixed results. There are both positive and negative trends in the development process of the innovative environment in Ukraine in recent years. Construction of the trend model will show possible changes in this situation over the next few years.

First of all, it is necessary to carry out the corresponding calculations (Table I).

TABLE I. INPUT DATA FOR TREND MODEL CONSTRUCTION

\begin{tabular}{|c|c|c|c|c|c|c|}
\hline & $\mathbf{t}$ & $\mathbf{y}$ & $\mathbf{t}^{\mathbf{2}}$ & $\mathbf{y}^{\mathbf{2}}$ & $\mathbf{t}^{*} \mathbf{y}$ & $\mathbf{y}(\mathbf{t})$ \\
\cline { 2 - 7 } & 1 & 36.3 & 1 & 1317.69 & 36.3 & 35.82 \\
\cline { 2 - 7 } & 2 & 36.5 & 4 & 1332.25 & 73 & 36.37 \\
\cline { 2 - 7 } & 3 & 35.7 & 9 & 1274.49 & 107.1 & 36.92 \\
\cline { 2 - 7 } & 4 & 37.6 & 16 & 1413.76 & 150.4 & 37.47 \\
\cline { 2 - 7 } & 5 & 38.5 & 25 & 1482.25 & 192.5 & 38.02 \\
\hline Total & 15 & 184.6 & 55 & 6820.44 & 559.3 & 184.6 \\
\hline Mean & - & 36.92 & 11 & 1364.088 & 111.86 & 36.92 \\
\hline
\end{tabular}


Table I also presents a result of the application of the Least Square Method. Thus, the system of equations will be the following:

$$
\begin{aligned}
& 5 a+15 b=184.6 \\
& 15 a+55 b=559.3
\end{aligned}
$$

It is possible to get the equation of a trend model by solving a system of equations:

$$
\begin{aligned}
& y=0.55 t+35.27 \\
& \text { where } b=0.55 \text { and } a=35.27
\end{aligned}
$$

Therefore, it is reasonable to argue that the Global Innovation Index score of Ukraine tends to increase by an average of 0.55 points annually.

But in the current conditions of the development of international trade, such a result is not sufficient for Ukraine to reach a level of the moderate innovator. It once again confirms the need to create a favorable innovative environment.

SWOT analysis (Table II) allows systematizing the results of data analysis and statistical analysis and determining prospects and risks of creating and developing an innovative environment for promoting the internationalization of Ukrainian industrial companies in detail.

TABLE II. SWOT ANALYSIS OF PROSPECTS AND RISKS OF CREATING AND DEVELOPING AN INNOVATIVE ENVIRONMENT FOR INTERNATIONALIZATION OF UKRAINIAN INDUSTRIAL COMPANIES

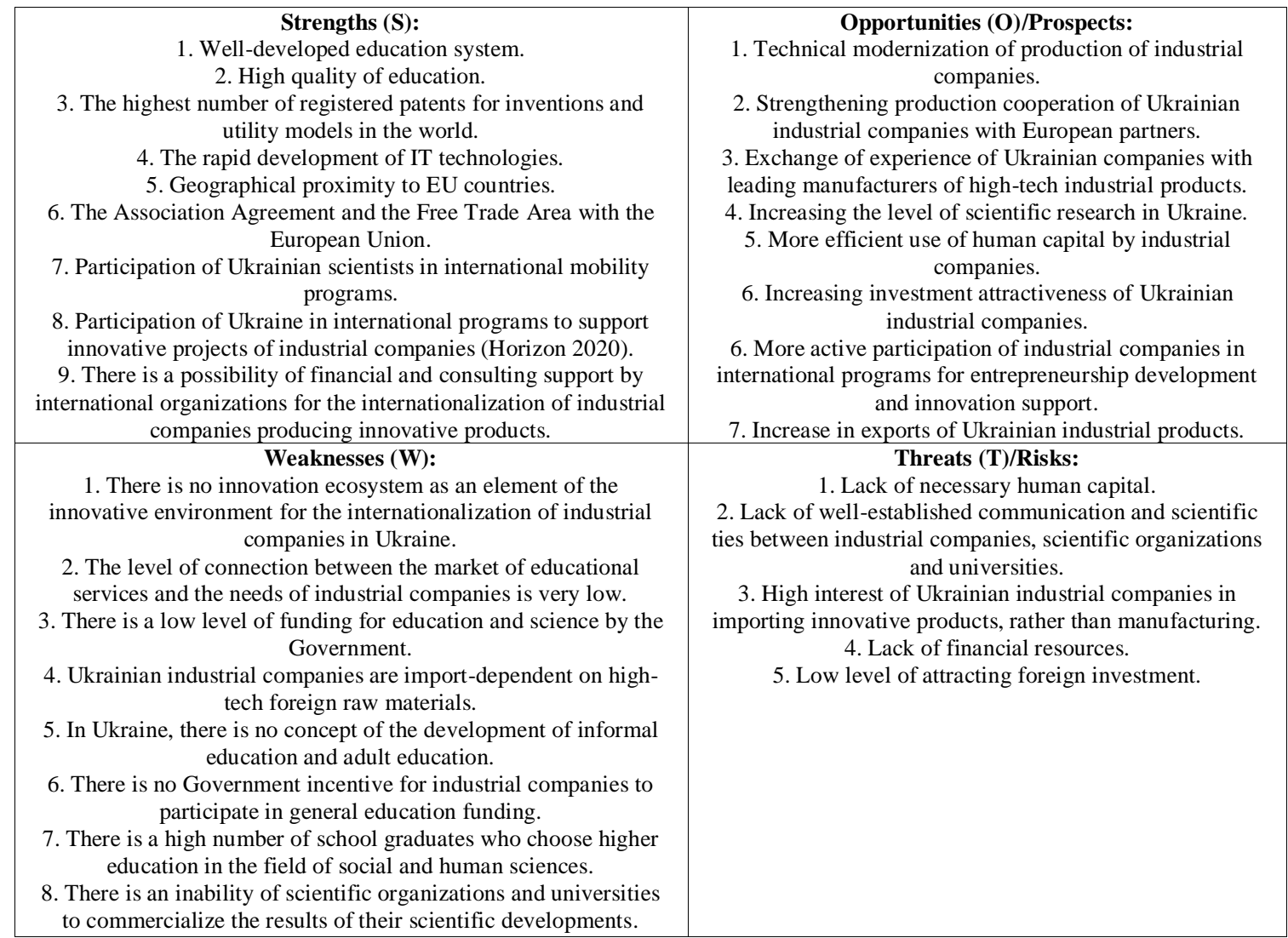

As shown by SWOT analysis, Ukraine has all the necessary resources to create a favorable innovative environment for the internationalization of industrial companies.

Solving the problems of financing education and science, stimulating the scientific cooperation of industrial companies with scientific organizations and universities, as well as creating an appropriate innovation ecosystem are some of the main tasks for the Ukrainian Government today.

\section{DISCUSSION AND CONCLUSIONS}

Creating an innovative environment for industrial companies internationalization in Ukraine has more prospects than risks. But, first of all, there is the problem of eliminating and minimizing the weaknesses presented in SWOT analysis.

First of all, the following measures are required:

- constant monitoring of the results of innovative activity at the state level;

- improvement of legislation in the field of regulation of innovative activity in Ukraine;

- creation of enabling business environment to enhance the attraction of foreign investment in industry;

- creation of innovative infrastructure through the effective implementation of Innovation Development Strategy of Ukraine;

- reform of the education system; 
- development of Programs for earmarked financing of innovation in industry;

- creation of an Innovation Platform based on interaction "Government - Science - Business";

- strengthen cooperation with international organizations to promote the innovative activity of industrial companies.

Without overcoming weaknesses, negative trends in the development of human resources, science and export can only increase. This will have a direct impact on reducing the innovation activity of industrial companies in Ukraine.

That is why the creation of an innovative environment for the internationalization of industrial companies requires a strategic approach.

\section{REFERENCES}

[1] Global Innovation Index. [Online] Available: https://www.globalinnovationindex.org/analysis-economy. Accessed on: Aug. 27, 2019.

[2] S. Becker, and P. Egger, "Endogenous product versus process innovation and a firm's propensity to export", Empirical Economics, Springer, vol. 44(1), pp. 329-354, Feb. 2013

[3] D. Legros, and G. Fabrice, "Are Innovation and R\&D the Only Sources of Firms' Knowledge that Increase Productivity? An Empirical Investigation of French Manufacturing Firms", Journal of Productivity Analysis, Springer, vol. 38(2), pp. 167-181, Oct. 2012.

[4] G. Azar, and F. Ciabuschi, "Organizational innovation, technological innovation, and export performance: The effect of innovation radicalness and extensiveness", International Business Review, vol. 26, Iss. 2, pp. 324-336, Apr. 2017.
[5] C. Camisón, and A. Villar-López, "Organizational innovation as an enabler of technological innovation capabilities and firm performance”, Journal of Business Research, vol. 67, Iss. 1, pp. 28912902, Jan. 2014.

[6] M.S.S. Krammer, "Science, technology, and innovation for economic competitiveness: The role of smart specialization in less-developed countries", Technological Forecasting and Social Change, Elsevier, vol. 123(C), pp. 95-107, 2017.

[7] G. M. Silva, Ch. Styles and L. F. Lages, "Breakthrough Innovation in International Business: The Impact of Tech-Innovation and MarketInnovation on Performance", International Business Review, vol. 26 (2), pp. 391-404, 2017.

[8] M. Talmar, B. Walrave, K. S. Podoynitsyna, J. Holmström and A. Georges L. Romme, "Mapping, analyzing and designing innovation ecosystems: the Ecosystem Pie Model”, Long Range Planning, 2018, in press.

[9] The World Bank. [Online]. Available: https://www.worldbank.org/en/publication/human-capital. Accessed on: Aug. 27, 2019.

[10] State Statistics Service of Ukraine. [Online]. Available: http://www.ukrstat.gov.ua/. Accessed on: Aug. 26, 2019.

[11] SCImago Journal \& Country Rank. [Online]. Available: www.scimagojr.com/countrysearch.php?country=ua. Accessed on: Aug. 27, 2019.

[12] European Innovation Scoreboard. [Online]. Available: https://ec.europa.eu/growth/industry/innovation/factsfigures/scoreboa rds_en. Accessed on: Aug. 26, 2019.

[13] Ukrainian Innovation Park UNIT.City. [Online]. Available: https://unitcitizen.com/wp-content/uploads/2018/05/UReport_finalversion_1.pdf. Accessed on: Aug. 27, 2019.

[14] Ministry of Education and Science of Ukraine. [Online]. Available: https://mon.gov.ua/ua/tag/mizhnarodni-naukovi-proektihe. Accessed on: Aug. 27, 2019. 